\title{
PEMBIAYAAN PINJAMAN LUNAK USAHA KECIL IKAN PATIN DENGAN PT. TELKOM PEKANBARU MELALUI MITRA BINAAN MENURUT EKONOMI ISLAM
}

\author{
Ficha Melina* \\ *Fakultas Agama Islam (FAI) Universitas Islam Riau (UIR) Pekanbaru \\ Jl. Kaharuddin Nasution No. 113 Perhentian marpoyan Pekanbaru 28284 \\ e-mail : $\underline{\text { fichamelina@fis.uir.ac.id }}$
}

\begin{abstract}
Abstrak : Penelitian ini dilakukan di PT. Telkom Pekanbaru dengan usaha kecil ikan patin di Desa Koto Mesjid Kecamatan XIII Koto Kampar Kabupaten Kampar. Adapun tujuan dalam penelitian yaitu untuk mengetahui pelaksanaan pembiayaan pinjaman lunak yang dilakukan oleh PT. Telkom Pekanbaru dengan usaha kecil ikan patin di Desa Koto Mesjid Kecamatan XIII Koto Kampar Kabupaten Kampar melalui Mitra Binaan, Dampak pembiayaan pinjaman lunak yang dilakukan PT. Telkom Pekanbaru dengan Mitra Binaan usaha kecil ikan patin di Desa Koto Masjid, Kecamatan XIII Koto Kampar, Kabupaten Kampar, serta untuk mengetahui tinjauan ekonomi Islam terhadap Kemitraan PT. Telkom Pekanbaru dalam membina Usaha Kecil ikan patin di Desa Koto Mesjid Kecamatan XIII Koto Kampar Kabupaten Kampar. Metode yang digunakan yaitu purposive sampling yang mana populasi dan sampel berjumlah 31 orang dimana 1 (satu) orang dari pihak PKBL PT. Telkom dan 30 Orang dari pengusaha ikan patin. Berdasarkan hasil penelitian bahwa pelaksanaan pembiayaan pinjaman lunak yang dilakukan PT. Telkom Pekanbaru dengan Mitra Binaan usaha kecil ikan patin di Desa Koto Masjid, Kecamatan XIII Koto Kampar, Kabupaten Kampar adalah dalam bentuk pemberian modal, melakukan pengawasan, pengarahan, dan pembinaan. Dampak dari pembiayaan pinjaman lunak yang dilakukan antara PT. Telkom Pekanbaru dengan Pengusaha Kecil Ikan Patin berdampak positif, dimana pengusaha kecil ikan patin dapat terbantu dalam pengembangan usahanya. Hal ini diketahui dari jumlah pendapatan dan kondisi usaha ikan patin yang semakin berkembang dengan adanya kerjasama dari PT. Telkom Pekanbaru. Dalam ekonomi Islam, pembiayaan pinjaman lunak yang dilakukan oleh PT. Telkom Pekanbaru dalam membina usaha kecil ikan patin mitra binaannya dibolehkan dalam Islam dengan prinsip tolong menolong, saling membutuhkan dan saling menguntungkan.
\end{abstract}

Kata Kunci : Mitra binaan, Pembiayaan pinjaman lunak 


\section{PENDAHULUAN}

Untuk lebih meningkatkan produksi dan pengembangan usaha kecil maka pemerintah telah berusaha membantu yang salah satunya dengan cara memberikan kredit, seperti kredit usaha kecil atau kebijaksanaan dalam penyisihan laba BUMN sebesar 1-2\% guna membina usaha kecil dengan pola kemitraan. Hal ini sesuai dengan surat keputusan yang dikeluarkan oleh Menteri Badan Usaha Milik Negara Republik Indonesia Nomor: PER-05/MBU/ 2013 tentang program kemitraan badan usaha milik negara dengan usaha kecil dan program bina lingkungan. Hal ini agar pengusaha kecil dapat berkembang dengan baik, dan dapat meningkatkan nilai ekonomi bangsa Indonesia sesuai dengan ajaran agama Islam.

Didalam Islam semua kegiatan ekonomi mendapatkan perhatian yang besar bahkan ekonomi Islam memperhatikan semua aktifitas ekonomi sejak pertama kali. Dalam firman Allah surah Al-Maidah ayat 2:

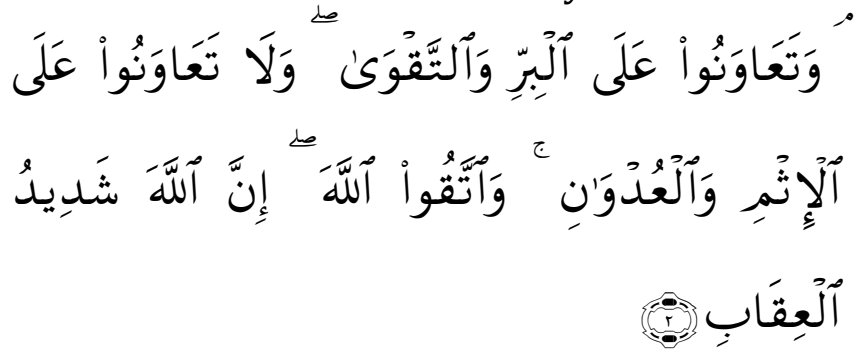

Artinya:..."Dan tolong-menolonglah kamu dalam (mengerjakan) kebajikan dan takwa, dan jangan tolong menolong dalam berbuat dosa dan pelanggaran. Dan bertakwalah kamu kepada Allah, sesungguhnya Allah amat berat siksa-Nya." (QS. Al-Maidah; 2).

Menurut ayat diatas tidak setiap bentuk tolong-menolong itu baik, melainkan ada juga yang tidak baik. Tolong-menolong yang baik adalah apabila mengarah pada kebaikan dan ketaqwaan sesuai petunjuk agama. Adapun tolong-menolong yang menyangkut masalah dosa dan permusuhan termasuk perkara yang dilarang agama. Tolong-menolong bebas dilakukan dengan siapapun (termasuk non muslim), selama tidak menyangkut masalah akidah dan ibadah. Dalam hal akidah dan ibadah tidak ada kompromi antara agama yang satu dengan yang lain.

Sektor usaha yang merupakan suatu lapangan bagi kegiatan ekonomi bagi jutaan penduduk Indonesia dewasa ini dan masa yang akan datang,maka tenaga kerja dan pengusaha yang tergolong rakyat kecil dan lemah dalam berbagai hal, lemah organisasi dan manajemen, lemah dari segi modal dan sebagainya sudah selayaknya mendapat lindungan dan pembinaan dari pemerintah agar mereka dapat tumbuh dan berkembang menjadi sesuatu kekuatan dalam pembangunan ekonomi. (Syarif, Forum Ekonomi No. 46,1999)

Pembiayaan pinjaman lunak merupakan salah satu bentuk dari tolong menolong. Salah satu pembiayaan pinjaman lunak yang baik adalah perusahaan BUMN memberikan bantuan berupa modal kepada pengusaha kecil yang mengalami kekurangan modal dan berharap dengan diberikan bantuan modal tersebut, pemerintah berharap para pengusaha kecil dapat berkembang dan perekonomian pun dapat meningkat menjadi lebih baik.

Dalam Islam, pembiayaan hutang piutang dapat di sebut dengan qardh. Qardh dalam arti bahasa berasal dari kata qarada yang sinonimnya qatha'a yang berarti memotong. Diartikan demikian karena orang yang memberikan utang memotong sebagian dari hartanya untuk diberikan kepada orang yang menerima utang (muqtaridh).

Pembiayaan pinjaman lunak dalam mengembangkan usaha kecil dan menengah atau yang disebut UKM adalah program kemitraan. Salah satu perusahaan yang diberi wewenang untuk memberikan dan menyalurkan bantuan modal bagi para pengusaha kecil adalah PT. Telkom. Mitra binaan PT. Telkom Pekanbaru adalah usaha kecil ikan patin di Desa Koto Masjid, Kecamatan XIII Koto Kampar Kabupaten 
Kampar,bentuk kemitraan yaitu pembinaan dan pemberian bantuan modal yang dilakukan oleh PT. Telkom Pekanbaru. Pemberian ini dilakukan kepada pengusaha kecil yang diharapkan mampu bersaing dan meningkatkan produktifitas sebagai bagian dari peningkatan produktifitas nasional.

\section{TINJAUAN PUSTAKA}

\section{Bisnis}

Dalam konteks pembicaraan umum, bisnis (business) tidak terlepas dari aktifitas produksi, pembelian, penjualan, maupun pertukaran barang dan jasa yang melibatkan orang atau perusahaan. Aktivitas dalam bisnis pada umumnya punya tujuan menghasilkan laba untuk kelangsungan hidup serta mengumpulkan cukup dana bagi pelaksanaan kegiatan si pelaku bisnis atau bisnisman (businessman) itu sendiri. (M. Fuad, Christin H, Nurlela, Sugiarto, Paulus, Y.E.F; 2000).

Dalam ilmu ekonomi, bisnis adalah suatu organisasi yang menjual barang atau jasa kepada konsumen atau bisnis lainnya, untuk mendapatkan laba. Secara historis kata bisnis dari bahasa Inggris business, dari kata dasar busy yang berarti "sibuk" dalam konteks individu, komunitas, ataupun masyarakat. Dalam artian, sibuk mengerjakan aktivitas dan pekerjaan yang mendatangkan keuntungan. Atau bisnis dalam arti luas adalah semua aktivitas oleh komunitas pemasok barang dan jasa.

\section{Pembiayaan}

Dalam arti sempit, pembiayaan dipakai untuk mendefinisikan pendanaan yang dilakukan oleh lembaga pembiayaan seperti BUMN kepada nasabah. Pembiayaan secara luas berartifinancing atau pembelanjaan yaitu pendanaan yang dikeluarkan untuk mendukung investasi yang telah direncanakan, baik dilakukan sendiri maupun dikerjakan oleh orang lain.

Tujuan pembiayaan berdasarkan prinsip syariah adalah untuk meningkatkan kesempatan kerja dan kesejahteraan ekonomi sesuai dengan nilai-nilai Islam. Pembiayaan tersebut harus dapat dinikmati oleh sebanyakbanyaknya pengusaha yang bergerak dibidang industri, pertanian, dan perdagangan untuk menunjang kesempatan kerja dan menunjang produksi dan distribusi barang-barang dan jasa-jasa dalam rangka memenuhi kebutuhan dalam negeri maupun ekspor. Memberikan pembiayaan dengan prinsip syariah yang menerapkan sistem bagi hasil yang tidak memberatkan debitur.

Pembiayaan Pinjaman Lunak adalah soft loan yaitu fasilitas pinjaman dengan syarat-syarat pelunasan ringan tingkat suku bunga rendah dan berjangka waktu panjang; fasilitas ini diberikan oleh bank pembangunan multilateral dan bilateral.

\section{Qardh}

Qardh dalam arti bahasa berasal dari kata qarada yang sinonimnya qatha'a yang berarti memotong.( Ibrahim Anis; 1972). Diartikan demikian karena orang yang memberikan utang memotong sebagian dari hartanya untuk diberikan kepada orang yang menerima utang (muqtaridh). (Muslich, 2010)

Di dalam fiqih Islam, hutang piutang telah dikenal dengan istilah Al-Qardh. Makna AlQardh secara etimologi (bahasa) ialah AlQath'u yang berarti memotong. Harta yang diserahkan kepada orang yang berhutang disebut Al-Qardh, karena merupakan potongan dari harta orang yang memberikan hutang kepada orang yang menerima utang.

\section{Program Kemitraan}

Menurut Mohammad Jafar Hafsah, "Kemitraan adalah suatu strategi bisnis yang dilakukan oleh dua pihak atau lebih dalam jangka waktu tertentu untuk meraih keuntungan bersama dengan prinsip saling membutuhkan dan saling membesarkan.

Hubungan usaha antara industri besar atau menengah dengan industri kecil dapat dijalin melalui empat model kemitraan yaitu (Sumarni, 1998):

1. Kemitraan Hulu-Hilir (Forward Linkage)

2. Kemitraan Hilir-Hulu (Backward Linkage)

3. Kerjasama Pemilikan Saham

4. Kerjasama Bapak-Anak Angkat 


\section{Usaha Kecil}

Usaha kecil adalah kegiatan usaha yang mempunyai modal awal yang kecil dan nilai kekayaan yang kecil dan jumlah pekerjaan yang juga kecil. (Sukirno, 2004).

Dilihat dari sifatnya industri kecil dibagi menjadi dua kelompok yaitu kelompok yang bersifat formal dan kelompok tradisional yang masih banyak berbentun informal. Formal adalah telah memenuhi syarat sebagai layaknya sebuah usaha, misalnya telah memiliki kantor dan badan usaha. Sedangkan Informal adalah belum memenuhi syarat yang layaknya sebagai sebuah usaha.

\section{Pembiayaan Kemitraan dalam Ekonomi Islam}

Hukum kemitraan dalam investasi, perdagangan, pertanian dan lain-lain, sehingga terus berkembang dan dipraktekkan oleh orang-orang. Ini merupakan salah satu bentuk tolong menolong dalam mendapatkan laba, dengan mengembangkan dan menginvestasikan harta, serta saling menukar keahlian.

Hukum Hutang piutang pada asalnya diperbolehkan dalam syariat Islam. Bahkan orang yang memberikan hutang atau pinjaman kepada orang lain yang sangat membutuhkan adalah hal yang disukai dan dianjurkan, karena di dalamnya terdapat pahala yang besar.

Yang menjadi landasan dalil dalam QS. AlBaqarah ayat 245 ini adalah kita diseru untuk "meminjamkan kepada Allah", yaitu untuk membelanjakan harta di jalan Allah. Berbanding lurus dengan meminjamkan kepada Allah, kita juga diseru untuk "meminjamkan kepada sesama manusia". Sebagai bagian dari hidup yang berkeimanan kepada Allah dengan bersikap saling tolong menolong dalam kehidupan bermasyarakat.

\section{METODE}

Penelitian ini merupakan penelitian lapangan dengan mengambil lokasi di Desa Koto Masjid, Kecamatan XIII Koto kampar, Kabupaten Kampar. Adapun yang menjadi pertimbangan daerah ini dijadikan penelitian yaitu terdapatnya pusat usaha ikan patin yang bersifat tradisional dan sederhana, dan lancarnya akses transportasi menuju Desa Koto Masjid, Kecamatan XIII Koto kampar, Kabupaten Kampar.

Adapun populasi dalam penelitian ini adalah PT. Telkom Pekanbaru yaitu Bagian Program Kemitraan dan Bina Lingkungan Daerah (PKBLD) berjumlah 1 orang dan dari pengusaha kecil ikan patin berjumlah 202 (dua ratus dua) orang. Dikarenakan jumlah populasi ini relatif banyak, maka penulis menggunakan sampel sebanyak dari 20\% yaitu 30 orang dan ditambah 1 orang dari pihak PT. Telkom. Jadi jumlah keseluruhan yaitu 31 orang, dengan menggunakan metode purfosive sampling.

Sedangkan Subjek dalam penelitian ini adalah Bagian Program Kemitraan dan Bina Lingkungan PT. Telkom Pekanbaru dan Pengusaha Kecil Ikan Patin di Desa Koto Masjid, Kecamatan XIII Koto Kampar, Kecamatan Kampar.

Dan Objek dalam penelitian adalah kerjasama usaha kecil ikan patin di Desa Koto Masjid, Kecamatan XIII Koto Kampar, Kabupaten Kampar dengan PT. Telkom Pekanbaru.

Untuk memperoleh data yang diperlukan penulis dengan menggunakan teknik pengumpulan data berupa, Observasi, Wawancara, Kuesioner dan Study Dokumentasi.

HASIL

Pembiayaan Kemitraan dalam Ekonomi Islam

Hukum kemitraan dalam investasi, perdagangan, pertanian dan lain-lain, sehingga terus berkembang dan dipraktekkan oleh orang-orang. Ini merupakan salah satu bentuk tolong menolong dalam mendapatkan laba, dengan mengembangkan dan menginvestasikan harta, serta saling menukar keahlian. 
Pelaksanaan Pembiayaan Pinjaman Lunak PT. Telkom Pekanbaru dengan Usaha Kecil Ikan Patin melalui Mitra Binaan.

Faktor yang mendukung tercapainya tujuan suatu program adalah pelaksanaannya. Apabila pelaksanaan suatu program baik dan tepat sasaran maka program ini akan dapat memberikan dampak bagi masyarakat. Adapun pelaksanaan program kemitraan PT. Telkom Pekanbaru berawal sejak tahun 2003. Program ini dilaksanakan guna meningkatkan kesejahteraan masyrakat khususnya pada masyarakat yang membutuhkan bantuan modal untuk menggeluti sebuah usaha. Komitmen PT. Telkom Pekanbaru "Menjamin hubungan yang harmonis dengan lingkungan diwilayahnya berupa kegiatan sosial kemasyarakatan dan tanggung jawab sosial (Good Corporate Citizenship). (Dokumentasi PT. Telkom Pekanbaru).

Program Kemitraan merupakan program untuk meningkatkan kemampuan usaha kecil agar menjadi tangguh dan mandiri melalui pemanfaatan dana bagian laba Badan Usaha Miliki Negara (BUMN). Program Bina Lingkungan adalah program pemberdayaan kondisi sosial masyarakat oleh BUMN melalui pemanfaatan dana dari bagian laba BUMN sebesar 1-2 \%. PT. Telkom Pekanbaru telah melakukan pembiayaan pinjaman lunak dengan pengusaha kecil dalam bentuk mitra binaan sejak tahun 2003. Sejak dicanangkan program pemerintah yang mewajibkan bagi seluruh perusahaan besar terutama BUMN untuk membantu para pengusaha kecil yang membutuhkan. Adapun Prosedur pengajuan bantuan mitra binaan (Dokumentasi PT. Telkom Pekanbaru):

1. Pengajuan proposal, proposal yang diajukan oleh calon mitra binaan kepada program kemitraan bina lingkungan PT. Telkom Pekanbaru;

2. Pencatatan proposal dan evaluasi proposal, proposal di catat dan di evaluasi kelengkapannya;

3. Survei calon mitra binaan, calon mitra binaan di verifikasi kelayakan dan kesiapan mendapatkan bantuan pinjaman oleh program kemitraan bina lingkungan;

4. Evaluasi dan penilaian hasil survei, hasil verifikasi diajukan untuk mendapatkan persetujuan;

5. Penetapan persetujuan calon mitra binaan, penetapan dilakukan oleh program kemitraan bina lingkungan;

6. Surat perjanjian pinjaman mitra binaan, disini calon mitra binaan menandatangani perjanjian pinjaman mitra binaan;

7. Penyerahan dana pinjaman mitra binaan, dana pinjaman ditransfer kepada mitra binaan.

Prosedur dan persyaratan yang diterapkan oleh PT. Telkom Pekanbaru kepada mitra binaannya khususnya pengusaha kecil ikan patin sangat mudah. Maka dari itu membuat para pengusaha kecil ikan patin tertarik untuk meminjam tambahan modal kepada PT. Telkom Pekanbaru dan dapat dilihat dari beberapa jawaban dari responden berikut ini.

Tabel.1

Jawaban Responden

Tentang Prosedur dan Persyaratan Pinjaman PT. Telkom Pekanbaru Sulit

\begin{tabular}{|c|c|c|c|}
\hline No & Jawaban & Jumlah & Persentase \\
\hline 1 & Ya & - & - \\
\hline 2 & Tidak & 30 & $100 \%$ \\
\hline 3 & Tidak Tahu & - & - \\
\hline 4 & Ragu-ragu & - & - \\
\hline & Total & 30 & $100 \%$ \\
\hline
\end{tabular}

Sumber: Data olahan, 2014 
Dari tabel diatas dapat diketahui bahwa jawaban responden tentang prosedur dan persyaratan yang diterapkan oleh PT. Telkom Pekanbaru, 30 responden atau 100\% mengatakan bahwa prosedur dan persyaratannya tidak sulit. Karena menurut responden, prosedur atau persyaratan yang diterapkan oleh PT. Telkom sangat mudah dan dapat membantu masyarakat yang benarbenar ingin berusaha.

\section{Dampak Pembiayaan Pinjaman Lunak antara Mitra Binaan usaha kecil ikan patin dengan PT. Telkom Pekanbaru}

Sejak tahun 2003, usaha kecil ikan patin yang menjadi mitra binaan PT. Telkom Pekanbaru. Pengembangan usaha nasional yang meliputi usaha kecil menengah dan koperasi, Badan Usaha Milik Negara (BUMN), dan Badan Usaha Milik Daerah (BUMD) serta usaha swasta diarahkan agar mampu tumbuh menjadi penggerak utama pembangunan ekonomi daerah khususnya di Desa Koto Masjid Kecamatan XIII Koto Kampar Kabupaten Kampar dalam memperluas kesempatan usaha dan kesempatan kerja menuju perekonomian daerah yang tangguh dan mandiri.

Usaha kecil ikan patin memiliki kendala dalam mengembangkan usahanya. Salah satu kendala yang dihadapi oleh pengusaha kecil ikan patin adalah keterbatasan modal usaha.
Modal merupakan salah satu dari beberapa fungsi produksi yang ada, dan modal merupakan salah satu sumber kekuatan yang paling utama dalam aktivitas dunia usaha khususnya usaha kecil. Oleh karena itu modal usaha mempunyai peran penting yang akan menentukan keberhasilan usaha kecil khususnya usaha kecil. (James dan Akrasane, 1993)

Dengan adanya bantuan dari PT. Telkom Pekanbaru berupa modal usaha dan binaan maka sangat membantu para pengusaha kecil ikan patin desa Koto Masjid untuk mengembangkan dan meningkatkan usahanya khususnya bagi para pengusaha kecil yang tergabung dalam mitra binaan PT. Telkom Pekanbaru. Dengan menjadi mitra binaan PT. Telkom Pekanbaru maka usaha yang dilakukan oleh pengusaha kecil ikan patin semakin meningkat, baik dari segi pendapatan, perkembangan usaha dan prooduksi yang dihasilkan.

Setelah menjadi mitra binaan PT. Telkom Pekanbaru, usaha kecil ikan patin desa Koto Masjid mengalami perubahan. Yang awalnya hanya beberapa rumah yang mempunyai kolam ikan patin, setelah menjadi mitra binaanPT. Telkom Pekanbaru sekarang sudah hampir rata-rata di setiap rumah memiliki kolam ikan patin. Berikut ini jawaban dari responden tentang kondisi usaha pengusaha kecil ikan patin setelah menjadi mitra binaan PT. Telkom Pekanbaru.

Tabel. 2

Jawaban Responden

Tentang Kondisi Usaha Setelah menjadi Mitra Binaan PT. Telkom Pekanbaru Membaik

\begin{tabular}{|c|c|c|c|}
\hline No & Jawaban & Jumlah & Persentase \\
\hline 1 & Ya & 26 & $86,67 \%$ \\
\hline 2 & Tidak & 4 & $13,33 \%$ \\
\hline 3 & Tidak Tahu & - & - \\
\hline 4 & Ragu-ragu & - & - \\
\hline & Total & 30 & $100 \%$ \\
\hline
\end{tabular}

Sumber: Data olahan, 2014 
Dari tabel di atas dapat diketahui bahwa kondisi usaha pengusaha kecil ikan patin yang bergabung dalam mitra binaan PT. Telkom Pekanbaru. Responden yang mengatakan Ya 26 responden atau 86,67\% mengatakan bahwa usaha ikan patin meningkat setelah menjadi mitra binaan PT. Telkom Pekanbaru dan 4 responden atau $13,33 \%$ mengatakan tidak, karena menurut responden, usaha mereka biasa saja tidak mengalami perubahan. Secara keseluruhan, kondisi usaha kecil ikan patin di Desa Koto Masjid mengalami peningkatan yang baik. Tetapi, ada beberapa orang responden mengatakan bahwa usahanya biasa-biasa saja, hal ini dikarenakan, usaha yang ia geluti mengalami pasang surut.

Pendapatan merupakan sasaran dan tujuan akhir yang hendak dicapai oleh setiap usaha adalah selisih antara jumlah penerimaan yang diterima dengan jumlah yang dibayarkan, dalam persaingan sempurna merupakan penjumlahan pembayaran kepada faktor-faktor produksi sesuai dengan produktivitas masing-masing. (Sukirno, 2004)

Berikut jawaban responden tentang tingkat pendapatan yang dihasilkan setelah menerima bantuan dari PT. Telkom Pekanbaru.

Tabel. 3

Jawaban Responden

Tentang Pendapatan Meningkat Setelah Menerima Bantuan dari PT. Telkom Pekanbaru

\begin{tabular}{|c|c|c|c|}
\hline No & Jawaban & Jumlah & Persentase \\
\hline 1 & Ya & 25 & $83,33 \%$ \\
\hline 2 & Tidak & 5 & $16,67 \%$ \\
\hline 3 & Tidak Tahu & - & - \\
\hline 4 & Ragu-ragu & - & - \\
\hline & Total & 30 & $100 \%$ \\
\hline
\end{tabular}

Sumber: Data olahan, 2014

Dari tabel diatas dapat diketahui bahwa 25 responden atau $83,33 \%$ mengatakan bahwa pendapatannya meningkat dan 5 responden atau 16,67\% mengatakan bahwa pendapatan mereka tidak meningkat. Kesimpulan dari jawaban responden tersebut bahwa nilai produksi setelah mendapat bantuan dari PT. Telkom

Pekanbaru bertambah seiring dengan bertambahnya modal usahanya. Dengan adanya mitra binaan ini dapat memberikan manfaat bagi pengusaha kecil ikan patin di desa Koto Masjid. Berikut ini berdasarkan jawaban responden tentang manfaat yang diberikan pinjaman kepada usaha kecil ikan patin.

Tabel. 4

Jawaban Responden

Tentang Pinjaman yang Diberikan PT. Telkom Pekanbaru Memberikan Manfaat

\begin{tabular}{|c|c|c|c|}
\hline No & Jawaban & Jumlah & Persentase \\
\hline 1 & Ya & 30 & $100 \%$ \\
\hline 2 & Tidak & - & - \\
\hline 3 & Tidak Tahu & - & - \\
\hline 4 & Ragu-ragu & - & - \\
\hline & Total & 30 & $100 \%$ \\
\hline
\end{tabular}

Sumber: Data olahan, 2014 
Dari tabel di atas dapat diketahui bahwa 30 responden atau 100\% mengatakan Ya kalau pinjaman yang disalurkan PT. Telkom melalui mitra binaannya memberikan manfaat bagi pengusaha kecil ikan patin.

Dalam mengembangkan suatu usaha tidak luput dari yang namanya kendala. Setiap

\section{Tabel. 5}

Jawaban Responden

Tentang Kendala yang di Alami Setelah Menjadi Mitra Binaan PT. Telkom Pekanbaru

\begin{tabular}{|c|c|c|c|}
\hline No & Jawaban & Jumlah & Persentase \\
\hline 1 & Ya & 9 & $30 \%$ \\
\hline 2 & Tidak & 20 & $66,67 \%$ \\
\hline 3 & Tidak Tahu & 1 & $3,33 \%$ \\
\hline 4 & Ragu-ragu & - & - \\
\hline & Total & 30 & $100 \%$ \\
\hline
\end{tabular}

Sumber: Data olahan, 2014

Dari tabel di atas dapat diketahui bahwa 9 responden atau 30\% mengatakan Ya, 20 responden atau $66,67 \%$ mengatakan Tidak, dan 1 responden atau $3,33 \%$ mengatakan Tidak tahu. Kesimpulannya adalah kendala dalam prosedur peminjamannya tidak ada. Akan tetapi kendala yang dihadapi oleh pengusaha kecil ikan patin salah satunya adalah sistem pemasarannya. Karena persaingan di dunia usaha, khususnya bagi pengusaha ikan patin semakin ketat.

\section{Tinjauan Ekonomi Islam tentang Kemitraan PT. Telkom Pekanbaru dalam Membina Usaha Kecil Ikan Patin.}

Dalam membahas perspektif ekonomi Islam, ada satu titik awal yang benar-benar harus kita perhatikan, yaitu ekonomi dalam Islam itu sesungguhnya bermuara kepada akidah Islam, yang bersumber dari Syari'at yaitu Al-Qur'an dan As-Sunnah. Adapun tujuan ekonomi Islam yaitu sebagai berikut:(Merza Gamal, 2004)

1. Kesejahteraan ekonomi dalam norma moral Islam

2. Membentuk masyarakat dengan tatanan sosial yang solid berdasarkan keadilan dan persaudaraan yang universal. usaha pasti akan memiliki kendala, baik berupa modal dan lain-lainnya. Berikut ini berdasarkan jawaban responden tentang kendala yang dialami pengusaha kecil ikan patin setelah menjadi mitra binaan PT. Telkom Pekanbaru. 
(rezki) dan kepada-Nya-lah kamu dikembalikan."(Al-Jumanatul 'Ali; 40)

Pembiayaan pinjaman lunak yang dilakukan oleh PT. Telkom Pekanbaru kepada pengusaha kecil ikan patin yang merupakan mitra binaan PT. Telkom adalah dengan memberikan pinjaman modal usaha. Dalam Islam memberikan pinjaman kepada orang yang membutuhkan diperintahkan dalam AlQur'an. Islam menganjurkan untuk memilih kehidupan dunia yang berdimensi akhirat. Dengan pilihan ini, maka seseorang akan mendapat tidak hanya kebaikan dalam kehidupan dunia yang pasti akan menjadi kebahagiaan di akhirat kelak. Inilah maksud dari bekerja itu merupakan ibadah, berdagang itu adalah ibadah dan tolong menolong terhadap sesama adalah ibadah dan seterusnya. Apabila hal tersebut dikerjakan dalam rangka ketaatan kepada Allah Swt.

Program kemitraan yang dilakukan oleh PT. Telkom Pekanbaru melalui pemberian pinjaman berupa modal usaha dibolehkan dalam Islam, bahkan sangat dianjurkan sebagai landasan tolong menolong terhadap sesama umat manusia dengan tujuan saling membantu, saling membutuhkan dan saling menguntungkan.

Sistem kemitraan yang dilakukan oleh PT. Telkom Pekanbaru ini dibolehkan dalam Islam, karena dengan adanya bantuan kemitraan dari PT. Telkom Pekanbaru dapat memberi bantuan kepada pengusaha kecil ikan patin yang terkendala dengan modal, dan dengan adanya kemitraan yang berupa pembiayaan pinjaman lunak ini dapat meningkatkan perekonomian masyarakat yang merupakan mitra binaan PT. Telkom Pekanbaru. Oleh karena itu, kemitraan PT. Telkom Pekanbaru berjalan sesuai dengan prinsip dan aturan Islam yang bertujuan untuk memaslahatkan dan mensejahterakan umat manusia. Namun, yang perlu diperbaiki dan diubah adalah sistem kerjasama dan kemitraan PT. Telkom Pekanbaru adalah pemberian pinjaman dengan bunga menjadi pembiayaan dengan sistem bagi hasil.

\section{SIMPULAN}

1. Pelaksanaan pembiayaan pinjaman lunak yang dilakukan PT. Telkom Pekanbaru dengan Mitra Binaan usaha kecil ikan patin di Desa Koto Masjid, Kecamatan XIII Koto Kampar, Kabupaten Kampar dalam mengembangkan dan mengelola usaha mitra binaannya adalah dari segi Permodalan, Melakukan Pembinaan, Memberikan Pengarahan dan Melakukan Pengawasan.

2. Dampak pembiayaan pinjaman lunak yang dilakukan PT. Telkom Pekanbaru dengan Mitra Binaan usaha kecil ikan patin di Desa Koto Masjid, Kecamatan XIII Koto Kampar, Kabupaten Kampar sangat berdampak positif bagi para pengusaha ikan patin tersebut. Dengan adanya bantuan dari PT. Telkom Pekanbaru berupa modal usaha dan binaan maka sangat membantu para pengusaha kecil ikan patin desa Koto Masjid untuk mengembangkan dan meningkatkan usahanya khususnya bagi para pengusaha kecil yang tergabung dalam mitra binaan PT. Telkom Pekanbaru. Dengan menjadi mitra binaan PT. Telkom Pekanbaru maka usaha yang dilakukan oleh pengusaha kecil ikan patin semakin meningkat, baik dari segi pendapatan, perkembangan usaha dan prooduksi yang dihasilkan. Setelah menjadi mitra binaan PT. Telkom Pekanbaru, usaha kecil ikan patin desa Koto Masjid mengalami perubahan. Yang awalnya hanya beberapa rumah yang mempunyai kolam ikan patin, setelah menjadi mitra binaan PT. Telkom Pekanbaru sekarang sudah hampir ratarata di setiap rumah memiliki kolam ikan patin. Berikut ini jawaban dari responden tentang kondisi usaha pengusaha kecil ikan patin setelah menjadi mitra binaan PT. Telkom Pekanbaru.

3. Sistem kemitraan yang dilakukan oleh PT. Telkom Pekanbaru ini dibolehkan dalam Islam, karena dengan adanya bantuan 
kemitraan dari PT. Telkom Pekanbaru dapat memberi bantuan kepada pengusaha kecil ikan patin yang terkendala dengan modal, dan dengan adanya kemitraan yang berupa pembiayaan pinjaman lunak ini dapat meningkatkan perekonomian masyarakat yang merupakan mitra binaan PT. Telkom Pekanbaru. Oleh karena itu, kemitraan PT. Telkom Pekanbaru berjalan sesuai dengan prinsip dan aturan Islam yang bertujuan untuk memaslahatkan dan mensejahterakan umat manusia. Namun, yang perlu diperbaiki dan diubah adalah sistem kerjasama dan kemitraan PT. Telkom Pekanbaru adalah pemberian pinjaman dengan bunga menjadi pembiayaan dengan sistem bagi hasil.

\section{DAFTAR RUJUKAN}

Arif, Muhammad. 2018. Analisis Rekrutmen dan Penempatan Kerja terhadap Kinerja Karyawan pada Hotel Oase. Jurnal Al-Hikmah: Vol. 15 (1): 42-63.

Ahmad Wardi Muslich, Fiqh Muamalat, (Jakarta: Amzah, 2010)

Al-Jumanatul 'Ali, Al-Quran dan Terjemahannya

Ibrahim Anis, et. Al, Al-Mu'jam Al-Wasith, Juz 2, Dar Ihya' At-Turats Al-'Arabiy, Kairo, Cet II, 1972

James dan Akrasane, Aspek-aspek finansial usaha kecil dan menengah, (Jakarta:LP3ES, 1993)

Murti Sumarni, Pengantar Bisnis (DasarDasar Ekonomi Perusahaan), (Yogyakarta: Liberty, 1998)

M. Fuad, Christin H, Nurlela, Sugiarto, Paulus, Y.E.F, Pengantar Bisnis, (Jakarta: Gramedia Pustaka Utama, 2000),

Merza Gamal, Aktifis Ekonomi Syariah, (Pekanbaru: UNRI Press, 2004), cet. 1

Sukirno Sadono, Pengantar Bisnis, (Jakarta: Kencana, 2004)

Subanar, Manajemen Usaha Kecil, (Yogyakarta, BPFE, 1997)
Suryana, Kewirausahaan (Pedoman Praktis: Kiat dan Proses Menuju Sukses), (Bandung: Salemba Empat, 2003)

S. Syarif, Pembinaan Sektor Informal di Indonesia Suatu Bahan Kajian, ( Forum Ekonomi No. 46,1999) 
